\title{
Caries Risk Assessment: Cariogram-An Insight
}

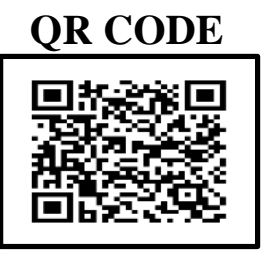

\section{MOHIT BANSAL ${ }^{* 1}$, RUHEE SANGHA ${ }^{2}$, SIMRAN $^{3}$, NAVDEEP KAUR WALIA ${ }^{4}$}

Dental caries is a public health problem. A new interactive graphical computerised system was introduced which is believed to record the caries risk assessment in less time depending upon a of number of factors. This paper focuses on the different sectors used in cariogram and its importance in reducing the caries risk.

KEYWORDS: Dental Caries, Risk Assessment, Cariogram

\section{INTRODUCTION}

Dental caries is a microbial disease of the calcified tissues of teeth, characterized by demineralization of inorganic portion and dissolution of organic substance of tooth. It is a multifactorial disease with several well-known, components participating in the disease process. ${ }^{1}$

Cariogram is an interactive version for estimation of caries risk, which was presented in 1996 by "Bratthal" for understanding the interactions of various factorsi) causing caries. The computer version presents a graphical picture that illustrates a possible overall caries risk scenario. The program contains an algorithm that presents a weighted analysis of biological factors. The process of making evolution is2) called "Cariography".

Cariogram was originally developed as an educational model. Later on, interactive version has found a place3) in education and discussions with patients concerning preservative strategies. Concept of caries risk assessment is simple and straightforward. ${ }^{2}$

Rationale of caries risk assessment is to: ${ }^{3}$

1) Identify those persons who will most likely develop caries.

2) Provide these individuals proper preservation and treatment measures to stop the disease.

Risk Model: It is used when it is important to identify one or more risk factors for the disease so that likely patients for intervention can be planned.

Prediction Model: It is used when one is mainly interested in identifying who is at risk to maximize sensitivity and specificity of the prediction, so that any good prediction may be included in the model.

\author{
APPROACHES OF RISK ASSESMENT 4 \\ 1) Past caries experience \\ 2) Socio-economic factors. \\ 3) Biological factors.
}

1) Past Caries Experience: This method is simple in experience and fast. It has been found that lesions, which develop early in life, tend to develop more lesions during coming years. These children are designated as "High Risk Individuals".

2) Socio-economic Factors: This factor can also select the high-risk individuals. People with poor socio-economic status are at a high risk.

3) Biological Factors: Factors that are actively operating in caries process are selected. It includes:

i) Bacteria.

ii) Diet - Composition and frequency of intake.

iii) Susceptibility - Saliva, fluoride exposure.

\section{WEIGHT - THE RELATIVE IMPACT OF FACTORS}

The factors included in the cariogram have been given different weights. It means the factor, which supports the development of caries / resist caries have a stronger impact then the less important factors.

\section{WHICH FACTORS ARE TO BE CONSIDERED IN ESTIMATION OF CARIES RISK}

Factors involved in caries process either have attack 
or defence mechanism at the site of development of lesion. Dental plaque, presence of specific microorganisms and diet can be included in attack side.

In defence site, salivary protective systems and fluoride exposure can be incorporated. These are the key factors determining if a caries lesion will occur or not at a specific tooth surface they are interacting.

Factors related to occurrence of caries without actually participating in development of lesion, so these group socio-economic factors and past caries experience can be added. Such factors can be designated as indicator of caries risk but do not participate actually in making of cavity.

\section{CARIOGRAM - ITS FIVE SECTORS:4}

The patient is examined and date is collected. The cariogram, a pie diagram is divided into five sectors of following colors (Figure 1).

1. Green: Shows an estimation of actual chance to avoid new cavities / caries. Chance of avoiding caries and risk of caries are expressions of same process but illustrated inversely i.e. when chance of avoiding caries are high, caries risk are smaller.

2. Dark Blue: Shows "Diet" which is based on a combination of diet contents and frequency.

3. Red: This sector shows bacteria and is based on combination of amount of plaque and mutans streptococci.

4. Light Blue: This sector denotes susceptibility which is based on a combination of fluoride programs, saliva secretion and saliva buffering capacity.

5. Yellow: Shows circumstances and is based on a combination of past caries experience and related diseases.

The bigger the green sector, better is from dental health point of view. Small green sector means high risk of caries. The bigger the other sectors, better is the health of an individual.

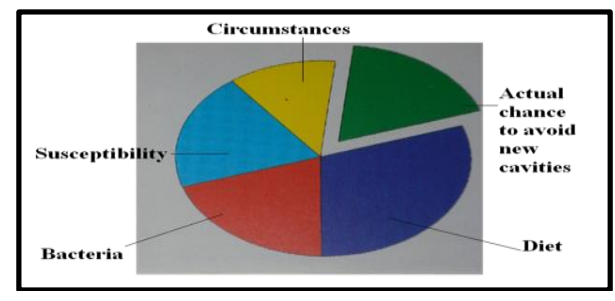

Figure 1. The Five Sectors of the Cariogram

\section{CARIOGRAM PRINCIPLES}

1. Full Circle: Illustrates unfavorable situations where caries will develop. There is enough bacteria, diet and susceptibility host. (Figure 2)

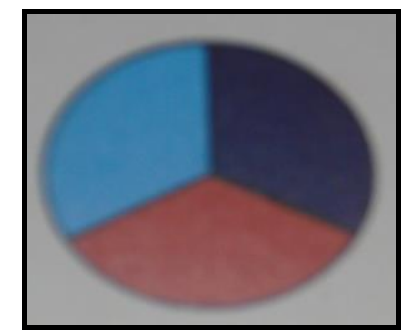

Figure 2. Full Circle

2. Broken Circle: Illustrates a situation where something is missing for cavity formation is a positive situation or open circle. (Figure 3)

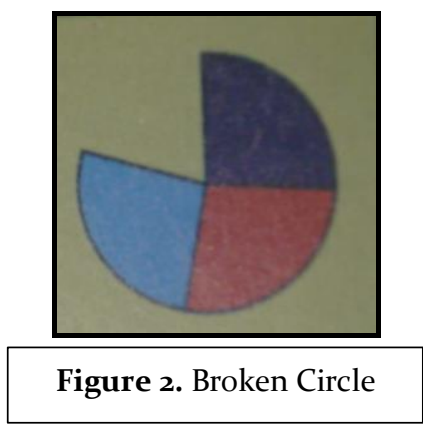

\section{CARIES RELATED FACTORS NEEDED TO CREATE CARIOGRAM ${ }^{5}$}

This can be seen from table 1.

\section{SCORING FOR THE DIFFERENT SECTORS}

To build a cariogram, scores for caries related factors are entered in the boxes on the right side. Score ranges from $0-3 \& 0-2$ respectively. The range is chosen accordingly after patient's examination.

\section{DIFFERENT SCORING PATTERNS}

o-3: - $\quad$ Caries experience.

- $\quad$ Diet Content

- Diet Frequency

- $\quad$ Plaque amount.

- Mutans streptococci

- $\quad$ Fluoride programme

- $\quad$ Saliva secretion.

o-2: - $\quad$ Related diseases. Buffer capacity. 
FACTOR

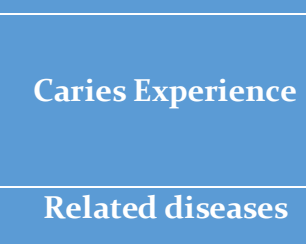

Diet contents

Diet frequency
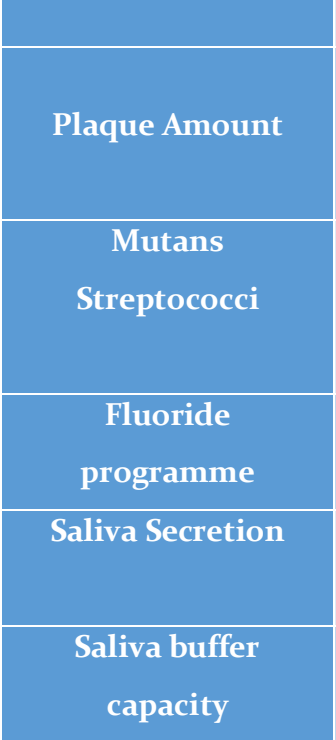

\section{COMMENT}

Past caries experience, including cavities, filling, missing teeth.

New cavities proceeding years should score ' 3 ' if no. of filling are low.

General or condition associated with caries.

Estimation of cariogenicity of food in particular sugar content.

Estimation of no. Of meals and snacks per day, mean for 'normal day'.

Estimation of oral hygiene of crowded teeth leading to difficulties in removing plaque inter-proximally should be taken into account (PI)

Estimation of levels of mutans streptococci in saliva using strip mutans test.

Estimation of what or tend fluoride is avoidable in oral cavity over coming period of time.

Estimation of amount of saliva e.g. using paraffin - stimulated secretion \& expressing results are min saliva per minute.

Estimation of capacity of saliva to buffer acids, e.g. using the dentobuff test.

\section{INFO / DATA NEEDED}

DMFT, DMFS, New caries

experience in past 1 year.

Medical history, medications.

Diet history, lactobacillus test count.

Questionnaire results $24 \mathrm{~h}$ recall on 3 days dietary recall.

Plaque Index

Strip mutans test or other

laboratory test giving comparable results.

Fluoride exposure interview patient.

Stimulated saliva test - secretion rate.

Dentobuff test or other laboratory tests giving comparable results.

Table 1. Caries Related Factors Needed to Create Cariogram5

SCORING CHART: This can be seen from table 2 .

\begin{tabular}{|c|c|c|}
\hline \multirow{4}{*}{$\begin{array}{l}\text { CARIOGRAM WILL APPEAR WERE WHEN ALL THE } \\
\text { SCORES WILL BE ENTERED. }\end{array}$} & \multicolumn{2}{|c|}{ STANDARD SET } \\
\hline & Caries Experience & $\mathbf{o}-3$ \\
\hline & Related Disease & $\mathbf{o}-\mathbf{2}$ \\
\hline & Diet Content & $\mathbf{o}-3$ \\
\hline & Diet Frequency & $\mathbf{o}-3$ \\
\hline & Plaque Amount & $\mathbf{o}-3$ \\
\hline Actual Change to audio new cavities & Mutans Streptococci & $\mathbf{o}-3$ \\
\hline Diet & Fluoride Programme & $\mathbf{o}-3$ \\
\hline Bacteria & Saliva Secretion & $\mathbf{o}-\mathbf{2}$ \\
\hline Susceptibility & Buffer Capacity & $\mathbf{o}-3$ \\
\hline Circumstances & Clinical Judgment & $\mathbf{o}-3$ \\
\hline
\end{tabular}

Table 2. Scoring Chart 


\section{EXPLANATION OF SCORES TO BE ENTERED}

1. CARIES EXPERIENCE4: This can be seen from table 3 .

\begin{tabular}{ll}
\hline SCORE & EXPLANATION \\
\hline o- No disease & $\begin{array}{l}\text { No signs of general } \\
\text { disease, patient is } \\
\text { healthy. }\end{array}$ \\
\hline 1 - Disease / condition & $\begin{array}{l}\text { A general disease can } \\
\text { affect dental caries e.g. } \\
\text { mild degree }\end{array}$ \\
\hline 2 - Sever degree, long & $\begin{array}{l}\text { Patients could be bed } \\
\text { ridden or may need } \\
\text { continuous medication. }\end{array}$ \\
\hline lasting
\end{tabular}

Table 3. Recording of Caries Experience

\section{HOW TO CALCULATE DMFT}

The patient is examined clinically for all his teeth except for $3^{\text {rd }}$ molar. If the caries in premolars is high, it means that the patient has been susceptible to disease during a past period of time. In older patients, DMFT is unsafe as several teeth could have been extracted other than carious e.g. due to periodontal disease.

\section{RELATED GENERAL DISEASE}

Several general diseases can directly or indirectly influence caries process either through affecting saliva formation and composition or through a caries inducing dietary portion.

\section{e.g. - Sjogren syndrome}

- Intake of medicines

- Radiation towards head and neck region.

Other problems like poor eyesight also may affect oral hygiene measures. (Table 4)

\begin{tabular}{l|l}
\hline SCORE & EXPLANATION \\
\hline 0-No disease & $\begin{array}{l}\text { No signs of general } \\
\text { disease patient is } \\
\text { healthy. }\end{array}$ \\
\hline 1 - Disease / condition & $\begin{array}{l}\text { A general disease can } \\
\text { affect dental caries e.g. } \\
\text { per eyesight. }\end{array}$ \\
mild degree & $\begin{array}{l}\text { Patients could be bed } \\
\text { ridden or may need } \\
\text { continuous medication. }\end{array}$ \\
\hline 2 - Sever degree, lo \\
lasting
\end{tabular}

\section{DIET CONTENT 4}

This is shown in table 5

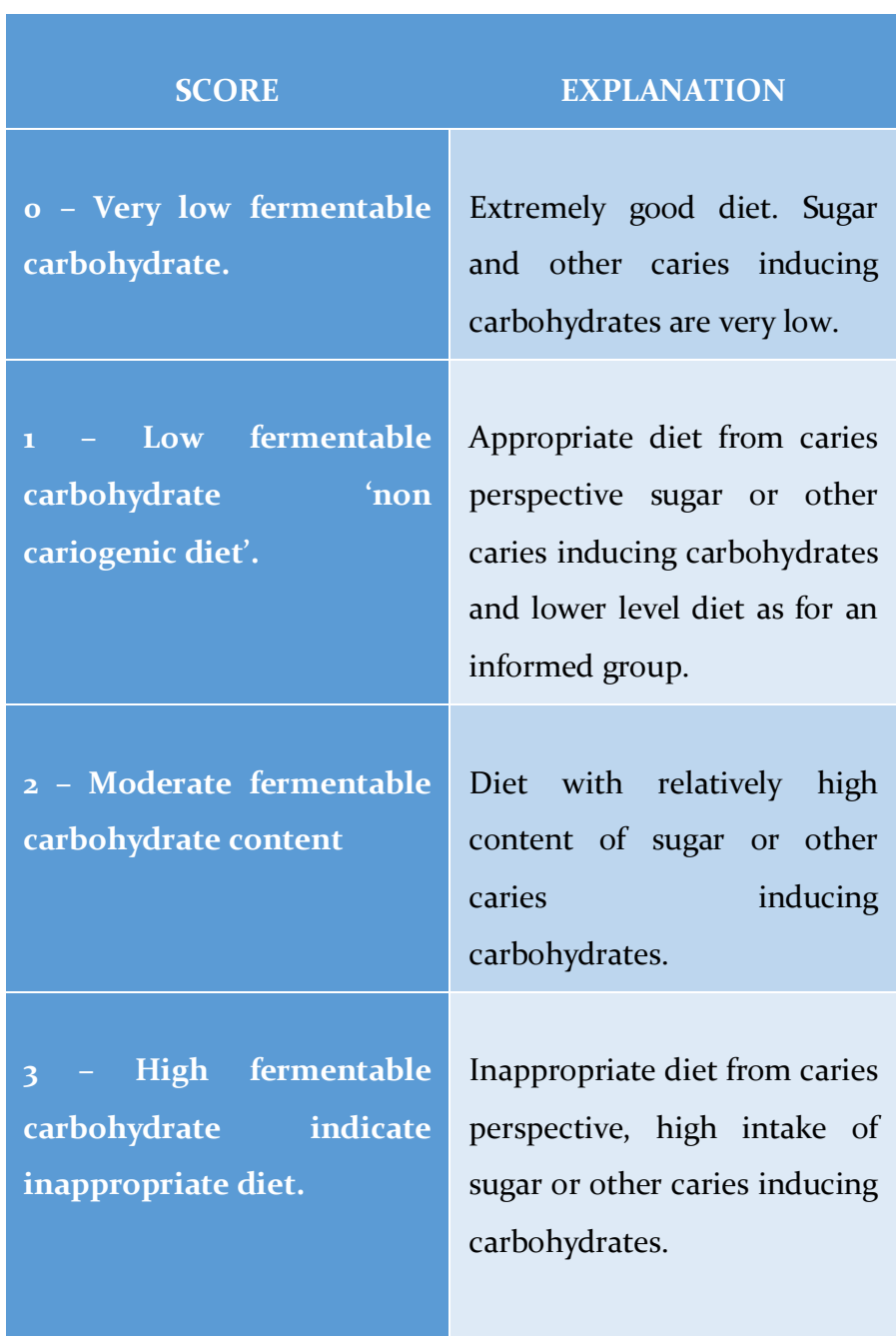

Table 5. Diet Content

Frequency of intake of fermentable carbohydrates is one of risky factor for estimation of caries. Even a small snack can produce acid.

Only sugar free snacks are not taken into consideration.

There are various methods by which a patient can be evaluated. For e.g.: intake frequency questionnaire are asked or by interview method (24 hours recall).

Table 4. Calculation of Related General Disease 


\section{PLAQUE AMOUNT 4}

Plaque is the direct and important etiological factor for caries, different indices are used to estimate the plaque amount e.g. Plaque index. (Table 6)

\begin{tabular}{|c|c|}
\hline SCORE & EXPLANATION \\
\hline $\begin{array}{l}\text { o - Extreme good oral } \\
\text { hygiene } \\
\text { PI } \rightarrow<<4 .\end{array}$ & $\begin{array}{l}\text { No plaque all teeth surfaces } \\
\text { are very clean. Very oral } \\
\text { hygiene conscious patient } \\
\text { uses both tooth brush and } \\
\text { inter dental cleaning. }\end{array}$ \\
\hline $\begin{array}{l}\text { 1 - Good Oral Hygiene } \\
\text { PI - > .4-1.0 }\end{array}$ & $\begin{array}{l}\text { A film of plaque adhering } \\
\text { to free gingival margin and } \\
\text { adjacent areas of tooth. } \\
\text { Plaque may be seen is situ } \\
\text { only after application of } \\
\text { disclosing solution or by } \\
\text { closing probe on tooth } \\
\text { surface. }\end{array}$ \\
\hline $\begin{array}{l}2 \text { - Less then good oral } \\
\text { hygiene } \\
\text { PT - 1.1. - } 2 \\
\end{array}$ & $\begin{array}{l}\text { Moderate accumulation of } \\
\text { soft deposits, which can be } \\
\text { seen with naked eye. }\end{array}$ \\
\hline $\begin{array}{l}\text { 3- Poor oral hygiene } \\
\text { PT }>2.0\end{array}$ & $\begin{array}{l}\text { Abundance of soft matter } \\
\text { in their gingival pocket and } \\
\text { or on tooth and gingival } \\
\text { margin. Patient is } \\
\text { interested in cleaning the } \\
\text { teeth or has difficulties in } \\
\text { cleaning. }\end{array}$ \\
\hline
\end{tabular}

Table 6. Estimation of Plaque Amount

\section{MUTANS STREPTOCOCCI ${ }^{4}$}

Very high amount of mutans streptococci in saliva. More than $80 \%$ of tooth surface colonized by bacteria. (Table 7).

Mutans streptococci refer to a group of bacteria mainly s. mutans and s. sobrinus. They are considered to play an important role in development of caries. They grow on solid surfaces in mouth, i.e. teeth crowns or dentures. They have a localized way of growing, which means that in one and the same mouth, some teeth may carry bacteria while other do not.

Mutans streptococci are both acidogenic aciduric means that they can produce acids, which can dissolve the tooth substance and can even survive in low $\mathrm{pH}$ environment. They also produce extra cellular glucans, which help them to adhere tooth surface.

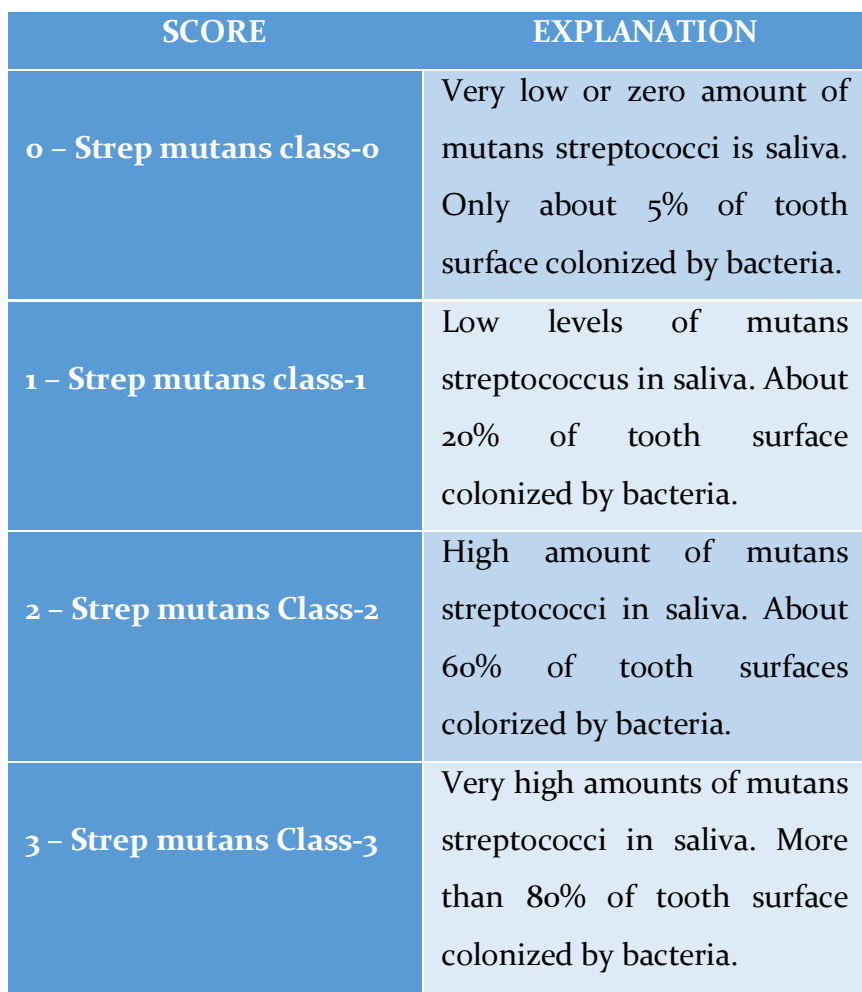

Table 7. Estimation of Mutans Streptococci

\section{FLUORIDE PROGRAMME ${ }^{4}$}

Fluorides are a very strong factor inducing resistance to caries. They cause remineralization of early carious lesions. (Table 8)

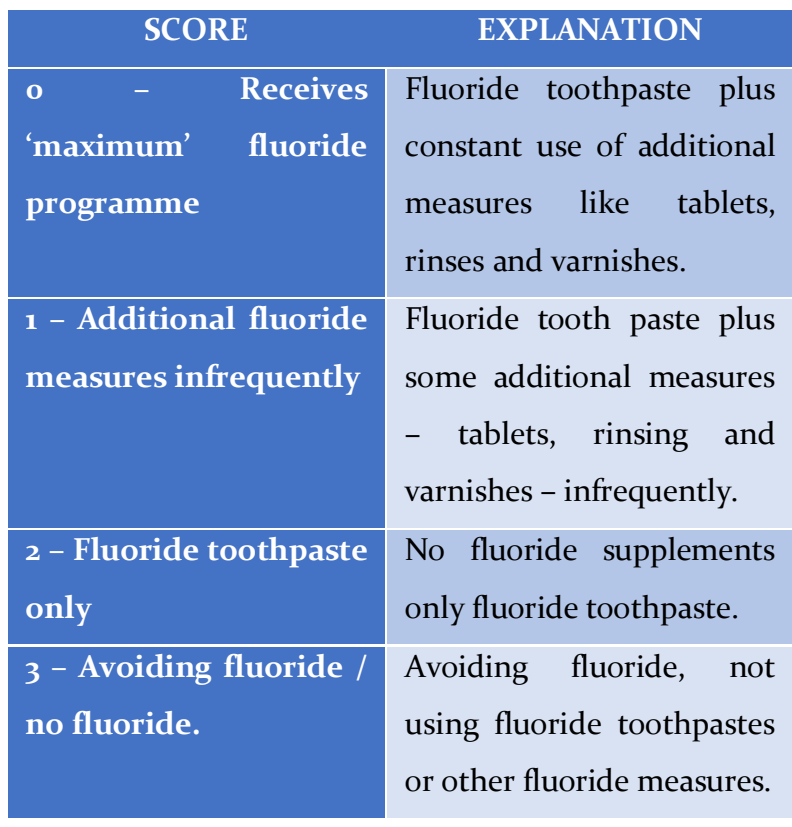

Table 8. Fluoride Programme 
SALIVA SECRETION AMOUNTS 4

This can be seen from table 9

\begin{tabular}{|c|c|}
\hline SCORE & EXPLANATION \\
\hline o - Normal & $\begin{array}{l}\text { More than } 1.1 \mathrm{ml} \text { stimulated saliva } \\
\text { / minute. }\end{array}$ \\
\hline 1 - Low & $\begin{array}{l}.9 \text { or less then } 1.1 \mathrm{ml} \text { stimulated } \\
\text { saliva / minute. }\end{array}$ \\
\hline 2 - Low & $\begin{array}{l}.5 \text { or less then } .9 \mathrm{ml} \text { stimulated } \\
\text { saliva / minute. }\end{array}$ \\
\hline 3-Very low & $\begin{array}{l}\text { Very low saliva secretion less then } \\
.5 \mathrm{ml} / \text { minute. }\end{array}$ \\
\hline
\end{tabular}

Table 9. Estimating the Salivary Secretion Amount

\section{METHODS OF COLLECTION OF SALIVA SECRETION 5}

Material Used: Paraffin and measuring cup.

1) Patient should neither eat, smoke for 1 hour.

2) Patient should be seated in upright relaxed position.

3) Paraffin pellet is given to patient to chew for 30 sec, and then spit out the saliva accumulated.

4)Patient continuous to chew for 5 minutes and after that the accumulated saliva is measured and secretion rate is calculated.

Normal saliva secretion: - $1 \mathrm{ml} /$ minute.

\section{SALIVA BUFFER CAPACITY 4}

This can be seen from table 10 .

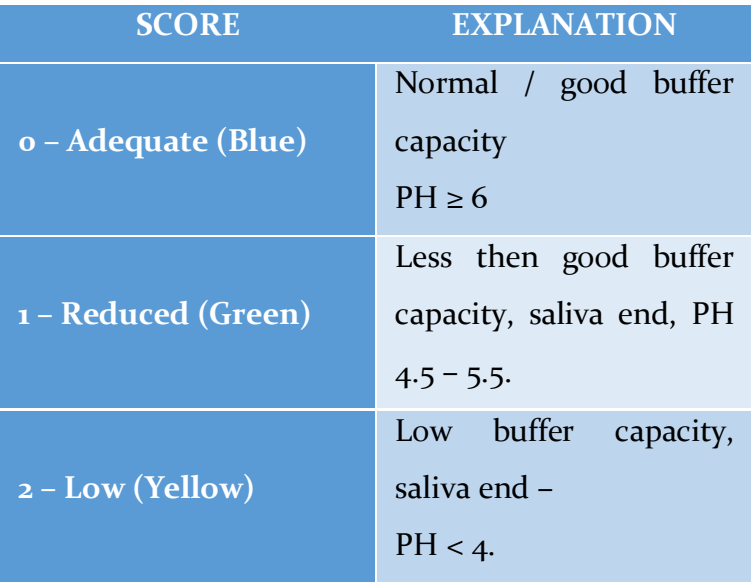

Table 1o. Estimating the Saliva Buffer Capacity

\section{METHOD OF EVALUATION OF SALIVA BUFFER CAPACITY}

Material Used: Dentobuff strip (indicator system incorporated in the test strip changes color)

1) Place Dentobuff strip, test facing pad up, on an absorbent surface without touching.

2) Use enclosed pipettes to apply drop of saliva to test pad.

3) After $5 \mathrm{~min}$, compare the color change developed on test pad with dentobuff strip color chart.

If buffer capacity: -

$\begin{array}{lll}\text { Low } & - & \text { Yellow Color } \\ \text { Medium } & - & \text { Green Color } \\ \text { High } & - & \text { Blue Color }\end{array}$

\section{CLINICAL JUDGEMENT 4}

Opinion of dental examiner 'Clinical feeling' (Table 11).

Clinical judgment is automatically pre-set to score-1. That value will let the other factors express the chance to avoid caries.

Total impression of caries situation, including social factors is very bad. Examiner is very sure that caries will occur in coming years and would want the green sector to be minimal irrespective of carving result. The examiner overrules programmers inbuilt estimation.

The score 'o' could be taken into consideration if other preventive actions have been installed which are not expressed in factors of the program. The score ' 3 ' has the greatest input of all the factors of the program, it means that you actually do not need cariogram, because cover rule judgment of the program.

\section{MEASURES TO REDUCE CARIES RISK \& ITS EFFECT ON CARIOGRAM}

1. Reducing Red Sector: ${ }^{6}$ Proper oral hygiene is needed. Tooth brushing twice a day can be seen as a minimum and where indicated, further measures should be installed after instruction from oral health personal, parent can be observant, so their children will have a chance to 


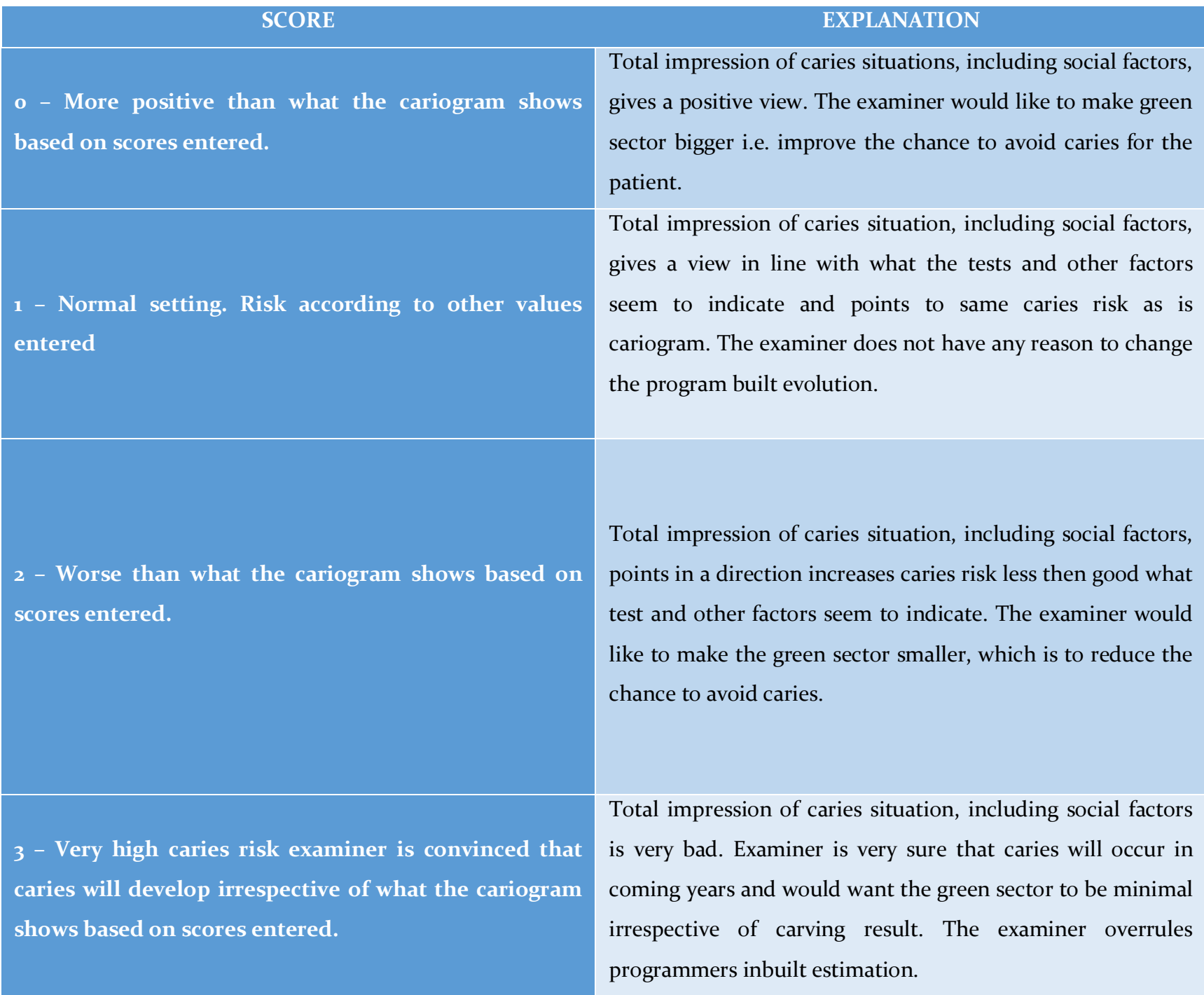

Table 11. Clinical Judgement of Cariogram

adopt a low cariogenic plaque covering as little as possible for teeth.

The dental personal can remove the plaque by mechanical tooth clearing. Wherever, indicated various antimicrobial solution or varnishes containing chrolohexidine can be applied professionally to reduce number of cariogenic microorganisms and patients can be instructed to follow up the treatment by proper home care.

2. Reduce blue sector - "diet factor": A sugar discipline is needed, unnecessary sugar intake should be avoided. However every substitute can be recommended.

Parents can be observant, so their children will have a chance to adopt proper diet both from general health and dental health point of view.

Dental personnel can analyze the situation by discussing the dietary pattern and identifying the products that should be avoided or reduced.

Also, analyzing the microbial flora for lactobacilli to get an idea about congeniality. Information regarding sugar free substitutes can be given. 
3. Reduce Susceptibly Factor: ${ }^{6}$ To reduce the susceptibility factor increase the resistance to dental caries / disease. Patient should have a proper fluoride exposure which promotes proper saliva secretion by proper chewing is recommended.

Dental personnel should analyze the situation by checking the saliva properties; in particular if saliva secretion is normal or not \& buffering capacity is functional. If any of these properties are failing, proper measures should be undertaken to improve the situation. Saliva substitutes are recommended in extreme situations.

For fluoride, dental professionals should or can prescribe or recommend proper supplements. Fluoride concentration at tooth surface can be strongly increased by applications from professionally administered products such as fluoride varnishes, gels and solutions. Patients can be instructed to follow up these treatments by proper home care.

It many cases, patients follow the instructions and the professional measures can be reduced step by step. For elderly patients and handicap patients repeated professional support for prolonged periods can be needed. Elderly population is more susceptible. It was found in a study that the overall risk for caries was twice as high for the elderly as for the children as assessed by the Cariogram. ${ }^{7}$

\section{PURPOSE OF CARIOGRAM 4}

1) To demonstrate caries risk graphically.

2) To assess and avoid new cavities in near future 'chance to avoid new cavities'.

3) If also illustrates to what extent various factors affect this chance.

4) To encourage preventive measures to be introduced before new cavities could develop.

\section{ADVANTAGES OF CARIOGRAM}

1) Expresses caries graphically.

2 Can easily be used by dentist in clinic.

3) Can be used as an educational programme.

4) Model is an affordable, user friendly and easy to understand to anyone.

\section{LIMITATIONS OF CARIOGRAM}

The cariogram expresses caries risk only. It does not take into account problems like fillings or discolorations that may make new fillings necessary.

\section{RELIABLITY OF CARIOGRAM MODEL AS CARIES RISK ASSESSMENT TOOL ${ }^{8}$}

The study was conducted in Jeddah by Dalia Abdullah Abu-Alenain to know the reliability of cariogram model as caries risk assessment tool. The study was conducted to compare the outcome of caries risk made by cariogram program on a set of patients. A questionnaire containing description of five patients was given to 70 dentists working in public health sector in Jeddah city. The result showed that $65.7 \%$ of dentists ranked the patients for caries risk identically as cariogram with only one deviation to the program. About $25.7 \%$ \& $8.6 \%$ ranked two \& one cases. Therefore it was concluded that cariogram could be a reliable tool for assessment of caries risk assessment that will give standardized results for different cases.

\section{CONCLUSION}

Cariogram is a new model for estimation of caries risk. So it helps in diet modification or maintain individual's oral hygiene to improve the general as well as the oral health of the person.

\section{REFERENCES}

1. Shafer WG, Hine MK, Levy BM. Textbook of Oral Pathology-fourth edition.

2. Axelsson P. Diagnosis \& Risk Prediction of Dental Caries. Quintessence Publishing Company $1^{\text {st }}$ ed. 2000;pp:172-4.

3. Hansel PG, Carlsson P, Bratthall D. Caries risk assessment: A comparison between the computer program "Cariogram", dental students and dental instructors. Eur J Dent Educ 1998; 2: 184-190.

4. Bratthall D, Petersson HG. Cariogram- A multifactorial risk assessment model for multifactorial diseases, Community Dent Oral Epidemiol 2005;33:256-64.

5. Hansel PG, Twetmann S, Bratthall D. Evaluation of a computer program for caries risk assessment in school children Caries Res 2002;36:327-340. 
6. Hansel PG, Fure S,. Evaluation of computer based risk assessment program in elderly group of individuals Acta Odontol Scand. 2003;61(3):16471.

Petersson HG. Assessing caries risk using cariogram model. Swed Dent J Suppl. 2003;(158):165.
8. Abu-Alenain DA. Reliability of a cariogram model as caries risk assessment tool. Cairo Dental Journal 2003; 19: 165-9.
Cite this article as:

Bansal M, Sangha R, Simran, Walia NK. Caries Risk Assessment: Cariogram-An Insight. Int Healthc Res J. 2019;3(5):167-175. https://doi.org/10.26440/IHRJ/0305.08272

\section{AUTHOR AFFILIATIONS AND CORRESPONDING ADDRESS:}

1. Associate Professor \& Head, Department of Public Health Dentistry, Rayat Bahra Dental College \& Hospital, Mohali (Punjab) (Corresponding Author)

2. $\quad$ Reader, Department of Prosthodontics, Rayat Bahra Dental College \& Hospital, Mohali (Punjab)

3. Tutor, Department of Prosthodontics, Rayat Bahra Dental College \& Hospital, Mohali (Punjab)

4. Reader, Department of Public Health Dentistry, BJS Dental College and Hospital, Ludhiana (Punjab) 